International Business and Global Economy 2018, no. 37, pp. 323-335

Biznes międzynarodowy w gospodarce globalnej 2018, nr 37, s. 323-335

Edited by the Institute of International Business, University of Gdańsk

ISSN 2300-6102

e-ISSN 2353-9496

DOI 10.4467/23539496IB.18.023.9396

Artur Sajnóg

Uniwersytet Łódzki

\title{
Przydatność kategorii zysku całkowitego w zarządzaniu finansami polskich i niemieckich spółek giełdowych
}

Wiodącym nurtem badań o charakterze teoretyczno-empirycznym jest ocena przydatności wyniku całkowitego w zarządzaniu finansami polskich i niemieckich spółek publicznych. Ważny element procesu badawczego stanowi komparatywna ocena formy prezentacji wyniku całkowitego i jego komponentów oraz wartości i zróżnicowania pozostałego wyniku całkowitego w porównaniu z zyskiem netto, z punktu widzenia udziału w kapitale własnym i kapitale całkowitym. Badaniem objęto spółki akcyjne notowane na GPW w Warszawie z indeksu WIG30 oraz spółki notowane na GPW we Frankfurcie z indeksu DAX (stan na 15 stycznia 2018 r.). Dane empiryczne do badania uzyskano z rocznych sprawozdań finansowych (za lata 2009-2016) z bazy Thomson Reuters. W badanych spółkach zidentyfikowano zróżnicowane warianty prezentacji i nomenklatury wyniku całkowitego oraz jego komponentów. Ponadto wyniki przeprowadzonych badań pokazały, że istotność pozostałego wyniku całościowego, w porównaniu z zyskiem netto, z punktu widzenia udziału w kapitale własnym i kapitale całkowitym, była niewielka. Zaobserwowano jednakże znaczącą przewagę przydatności wyniku całkowitego w spółkach niemieckich w porównaniu z polskimi przedsiębiorstwami.

Słowa kluczowe: wynik całkowity, pozostały wynik całkowity, zarządzanie finansami, raportowanie finansowe, polskie i niemieckie spółki publiczne

Klasyfikacja JEL: G21, M41, M48

\section{Usefulness of comprehensive income for finance management of Polish and German public companies}

The main objective of the paper is an evaluation of the usefulness of comprehensive income for finance management of Polish and German public companies. An important element of the research was a comparative analysis of the form of presentation of comprehensive income and its components and an analysis of the scale and diversity of other comprehensive income in comparison to net profit from the point of view of its share in equity and total capital. The research covers joint-stock companies listed on the Warsaw Stock Exchange (included in the WIG30 index) and the Frankfurt Stock Exchange (included in the DAX index) (data for 15 January 2018). Empirical data was obtained from annual financial statements (from 2009 to 2016) from Thomson Reuters database. Diversified variants of presentation and terminology of comprehensive income and its components have been identified. The results of the research indicate that the importance of 
other comprehensive income in comparison to net profit, as part of equity and total capital, was insignificant. However, significantly higher usefulness of comprehensive income in German companies has been observed.

Keywords: comprehensive income, other comprehensive income, finance management, financial reporting, Polish and German public companies

JEL classification: G21, M41, M48

\section{Wprowadzenie}

Pomiar finansowych osiągnięć przedsiębiorstw funkcjonujących na międzynarodowym rynku kapitałowym odgrywał i odgrywa kluczową rolę w zarządzaniu finansami, rozumianym jako proces równoległych działań, które zapewniają danemu podmiotowi maksymalizację ekonomicznych korzyści oraz źródeł pozyskiwania środków na sfinansowanie ich realizacji. Przez dziesięciolecia za kluczowy miernik efektywności zarządzania finansami przedsiębiorstwa uznawano niewątpliwie zysk netto, kojarzony z oceną dokonań przedsiębiorstwa i jego zarządu w danym okresie. Jednakże wraz z rozpowszechnieniem się w końcu XX w. koncepcji zarządzania zyskiem (earnings management), która cieszy się coraz większym zainteresowaniem menedżerów, zaczęto dostrzegać, iż kierownictwo firmy często pomija w swych analizach informacje o innych komponentach i kategoriach finansowych, które z punktu widzenia właściciela świadczą finalnie o przyroście jego dobrobytu (bogactwa). Swego rodzaju odpowiedź na ów problem stanowiły zmiany $\mathrm{w}$ regulacjach dotyczących rachunkowości, które doprowadziły do egzekwowania prezentacji wyniku całkowitego jako miernika finansowego pokazującego zmianę po stronie aktywów netto.

Ujawnienie w sprawozdawczości finansowej zysku całkowitego od samego początku praktycznego jego zastosowania stało się kwestią sporną zarówno dla teoretyków, jak i praktyków zarządzania finansami. Zysk całkowity jako kategoria, która uwzględnia wszelkie zmiany po stronie kapitału własnego (poza dokonanymi przez właścicieli i na ich rzecz), z założenia jest bogatszy informacyjnie niż zysk netto i winien posiadać większą wartość użytkową, jeśli chodzi o podejmowanie decyzji w zakresie doboru optymalnej wielkości i struktury kapitałów oraz ich lokowania $\mathrm{w}$ przedsięwzięciach korzystnych z punktu widzenia celu przedsiębiorstwa.

Zasadniczym celem opracowania jest ocena przydatności wyniku całkowitego w zarządzaniu finansami polskich i niemieckich spółek giełdowych, w szczególności analiza jego poziomu i struktury w badanych jednostkach, która może wskazać nie tylko na znaczne zróżnicowanie, lecz także na odmienną jego użyteczność w procesie podejmowania decyzji. Można bowiem przypuszczać, iż na skutek znacznej swobody w sporządzaniu sprawozdań finansowych wedle 
Międzynarodowych Standardów Rachunkowości w badanych jednostkach mogą pojawić się różnice $\mathrm{w}$ sposobie prezentacji wyniku całkowitego oraz jego komponentów. Ponadto, zróżnicowana wartość i struktura pozostałego wyniku całkowitego może nie sprzyjać jasności i przejrzystości przekazywanych informacji, a w efekcie użyteczności tej kategorii dla potrzeb zarządzania finansami spółek giełdowych.

Tak sformułowane cele badawcze i przypuszczenia zostały zweryfikowane na podstawie analizy rocznych sprawozdań finansowych spółek notowanych na GPW w Warszawie z indeksu WIG30 oraz spółek notowanych na GPW we Frankfurcie nad Menem z indeksu DAX (stan na 15 stycznia 2018 r.) za lata 2009-2016, dostępnych w bazie Thomson Reuters. Wybór do analizy spółek z dwóch równolicznych indeksów podyktowany został potrzebą zachowania transparentności i porównywalności danych między jednostkami wchodzącymi w ich skład.

W ramach procesu badawczego analizie poddano jednolitość $\mathrm{w}$ zakresie form i zasad prezentacji wyniku całkowitego, jego struktury oraz poszczególnych pozycji, zwłaszcza udział składników pozostałego wyniku całkowitego w wyniku całkowitym. Zbadano także relacje innych całkowitych dochodów do kapitału własnego i kapitału całkowitego.

\section{Wynik całkowity i sposoby jego prezentacji}

Wynik (zysk, dochód) całkowity (comprehensive income) jest efektem pomiaru wyniku finansowego przedsiębiorstwa, rozumianego nie jako tradycyjne porównanie różnego rodzaju przychodów i kosztów, ale wszelkich zmian po stronie kapitału własnego (aktywów netto) z wyłączeniem transakcji z właścicielami [Cimini, 2013, s. 1-17]. W tym ujęciu za zysk należy uznać każdy wzrost wartości kapitału własnego, powstały na skutek wszelkich transakcji dla danego podmiotu gospodarczego, poza tymi, które dotyczą inwestycji dokonanych przez właścicieli i dystrybucji aktywów na ich rzecz [Turyna, 2003, s. 158]. W szczególności chodzi o zmiany po stronie kapitału własnego, wynikające z emisji akcji i ich ceny emisyjnej wyższej niż nominalna lub z podziału wyniku finansowego z poprzednich okresów, ale niestanowiące przesunięcia między pozycjami kapitału własnego. Można to wyrazić następująco:

$$
C I=\Delta E-\Delta \mathrm{E} S
$$

gdzie:

CI - wynik całkowity,

$\Delta E \quad$ - wszelkie zmiany po stronie kapitału własnego (wielkość na koniec okresu w porównaniu z wielkością na początku okresu), 
$\Delta E s \quad$ - zmiany po stronie kapitału własnego dotyczące rozliczeń właścicielskich lub będące konsekwencją podziału wyniku finansowego z poprzednich okresów, niestanowiącego przesunięcia między pozycjami kapitału własnego.

Zgodnie z regulacjami Międzynarodowych Standardów Rachunkowości wynik całkowity, obok wyniku finansowego netto, ustalanego w rachunku zysków i strat, zawiera składniki pozostałego wyniku całkowitego (other comprehensive income), co można wyrazić jako:

$$
C I=N I \pm O C I
$$

gdzie:

NI - wynik finansowy netto,

OCI - pozostały wynik całkowity.

Wśród elementów różnicujących wynik finansowy netto od wyniku całkowitego, czyli pozostałego wyniku całkowitego, wymienić można pięć kategorii [MSR, 2011, par. 81]:

1) zmiany $w$ nadwyżce $z$ przeszacowania środków trwałych oraz wartości niematerialnych,

2) zyski i straty aktuarialne z tytułu programu określonych świadczeń,

3) zyski i straty wynikające z przeliczenia pozycji sprawozdania finansowego jednostki działającej za granicą,

4) zyski i straty z tytułu przeszacowania składników aktywów finansowych dostępnych do sprzedaży,

5) efektywną część zysków i strat związanych z instrumentami zabezpieczającymi w ramach zabezpieczenia przepływów pieniężnych.
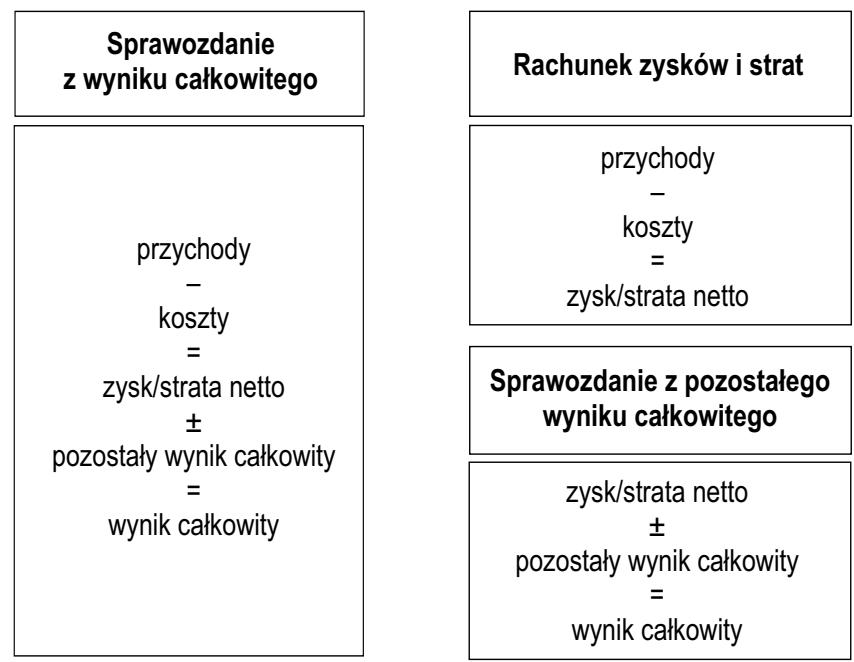

Rysunek 1. Dualne podejście do prezentacji sprawozdania z całkowitych dochodów Źródło: Opracowanie własne. 
Od 2009 r. polskie i niemieckie spółki publiczne notowane na giełdzie, które prowadzą politykę rachunkowości zgodną z MSR, są zobowiązane sporządzać sprawozdania z całkowitych dochodów (statements of comprehensive income) i tym samym wykazywać zarówno kwoty wyniku całkowitego, jak i poszczególnych pozycji pozostałego wyniku całkowitego. Mogą one jednak wybrać, czy wszelkie koszty i przychody prezentować w pojedynczym sprawozdaniu z całkowitych dochodów, czy też zawrzeć je w dwóch sprawozdaniach, tj. tradycyjnym rachunku zysków i strat oraz w drugim sprawozdaniu, które rozpoczyna się od zysku lub straty netto i ujawnia elementy innych całkowitych dochodów (rys. 1).

Założenia koncepcyjne prezentacji MSR pozwalają dodatkowo na elastyczność w zakresie stosowanej terminologii, prezentacji kosztów oraz ujmowania podatku dochodowego. Dla pozycji sprawozdania typu: „zyski i straty”, „całkowite dochody", ,inne całkowite dochody" dopuszcza się stosowanie innych określeń, jeśli ich znaczenie jest zrozumiałe [MSR, 2011, par. 7). Pozostawia się także wybór prezentacji kosztów w układzie porównawczym (rodzajowym) bądź w układzie kalkulacyjnym (funkcjonalnym), w zależności od tego, która forma prezentacji dostarcza informacji bardziej wiarygodnych i bardziej przydatnych [MSR, 2011, par. 99]. Ponadto, składniki pozostałego wyniku całkowitego można prezentować:

- pomniejszone o określone skutki podatkowe,

- przed ujęciem skutków podatkowych, z wykazaniem łącznej kwoty podatku dochodowego odnoszącej się do tych składników [MSR, 2011, par. 91].

\section{Przydatność zysku całkowitego w zarządzaniu finansami}

Wynik całkowity był przedmiotem wielu badań prowadzonych w Polsce i za granicą. Obszerne badania dotyczące formy prezentacji sprawozdania z całkowitych dochodów przez polskie spółki przeprowadzili m.in. Anna Szychta i Denise de la Rosa [Szychta, de la Rosa, 2012]. Zasadniczą kwestią sporną jest jednak pytanie, który wynik finansowy - netto czy całkowity - winien stanowić wiodącą podstawę efektywności zarządzania finansami przedsiębiorstw oraz oceny ich menedżerów. Analiza dotychczasowego dorobku naukowego wskazuje, iż w praktyce istnieje wiele kontrowersji dotyczących przewagi wyniku całkowitego nad wynikiem netto [Keating, 1999; Le Manh-Béna, 2009], a przedmiotem porównawczych badań czyniono istotność informacyjną tej kategorii dla rynków kapitałowych, jej trwałość w czasie czy wartość prognostyczną [Jones, Smith, 2011].

Zwolennicy kategorii wyniku całkowitego podkreślają, iż powinna ona cieszyć się coraz większym zainteresowaniem ze strony menedżerów, m.in. ze względu na fakt, iż większość strategii i technik zarządzania zyskami koncentruje 
się na zysku lub stracie netto, menedżerowie zaś często pomijają w swoich analizach informacje o innych całkowitych dochodach, które są równie istotne. Wynik całkowity posiada ponadto szereg innych atrybutów przydatności w zarządzaniu finansami przedsiębiorstw, m.in.:

- ujawnianie wyniku całkowitego w odrębnym sprawozdaniu ułatwia ocenę zarządzania efektywnością przedsiębiorstwa i poprawia jego przejrzystość [Hirst, Hopkins, 2007];

- wynik całkowity jest bardziej klarownym rezultatem finansowym dla menedżerów aniżeli wynik netto, gdyż wyraża m.in. większy potencjał przedsiębiorstwa do generowania zysków w przyszłości [Kanagaretman, Mathieu, Shehata, 2009];

- składniki pozostałego wyniku całkowitego wynikają z instrumentów finansowych, których efektywność zarządzania jest wskaźnikiem umiejętności i kwalifikacji kierownictwa [Keating, 1999];

- pozostały wynik całkowity ma bardziej istotną wartość zarządczą w porównaniu z wynikiem finansowym netto [Ramond, Casta, Lin, 2007; Pronobis, Zülch, 2011];

- wynik całkowity wydaje się mniej podatny na manipulacje księgowe i realizacje strategii zarządzania wynikiem finansowym [Hirst, Hopkins, 2007; Chambers i in., 2007].

Ponadto, z przeprowadzonych badań ankietowych wynika, iż użytkownicy sprawozdań finansowych wprost popierają ujawnienie składników wyniku całkowitego, ale są przeciwni ich prezentacji w odrębnym sprawozdaniu. Inne opinie inwestorów wskazują, że format prezentacji wyniku całkowitego nie ma znaczącego wpływu na postrzeganie informacji, jednakże jest ważny z punktu widzenia wynikających z niej decyzji inwestorów [Maines, McDaniel, 2000].

Krytycy wprowadzenia wyniku całkowitego do zarządzania finansami podmiotów gospodarczych zwracają z kolei uwagę na to, iż:

- wynik netto jest lepszym predyktorem wartości rynkowej kapitału własnego i dochodu niż wynik całkowity [Cahan i in., 2000],

- ani na poziomie zagregowanym, ani sektorowym wynik całkowity nie jest lepszą miarą wyników przedsiębiorstwa ocenianych na podstawie stóp zwrotu w porównaniu z wynikiem finansowym netto [Dastgir, Velashani, 2008],

- w zarządzaniu finansami należy skupić się na trwałych komponentach wyniku finansowego netto, a nie przejściowych składnikach wyniku całkowitego [Black, 1993],

- wyodrębnianie elementów pozostałego wyniku całkowitego zmniejsza możliwość wykorzystania tej kategorii jako źródła istotnych informacji na potrzeby przyszłych prognoz [Dhaliwal, Subramanyam, Trezevant, 1999]. 
Dodatkowo, z dotychczasowych polskich badań empirycznych wynika niewielka użyteczność zysku całkowitego w predykcji przyszłych wyników finansowych [Sajnóg, 2017].

Biorąc pod uwagę zarówno pozytywne, jak i negatywne argumenty odnoszące się do przydatności wyniku całkowitego $\mathrm{w}$ zarządzaniu finansami przedsiębiorstw, należy zasugerować, iż z punktu widzenia menedżera w analizie finansowych efektów działalności gospodarczej, prócz składowych wyniku finansowego netto, warto uwzględnić elementy pozostałego wyniku finansowego, które obrazują istotne zmiany po stronie kapitału własnego bezpośrednio lub pośrednio związane z bieżącą działalnością podmiotu. $\mathrm{W}$ tym miejscu należy podkreślić, iż wynik finansowy netto, sporządzany zgodnie z koncepcją bieżącego zysku operacyjnego, odzwierciedla dokonania jednostki, czyli obejmuje swoim zakresem obszar, na który bezpośredni wpływ mają menedżerowie jednostki. Pozostały wynik całkowity dotyczy z kolei obszaru, na który menedżerowie mają bardziej ograniczony wpływ i który jest uzależniony od zewnętrznych uwarunkowań przedsiębiorstwa. Łączna analiza kształtowania się wyniku finansowego netto, pozostałego wyniku całkowitego oraz wyniku całkowitego, polegająca na wyodrębnieniu jednego z sześciu możliwych wariantów (tab. 1), może stanowić podstawę wyciągnięcia generalnych wniosków odnoszących się do jakości zarządzania finansami.

Tabela 1. Warianty kształtowania się podstawowych pozycji sprawozdania z całkowitych dochodów

\begin{tabular}{|c|c|c|c|}
\hline Wariant & NI & OCI & $C I$ \\
\hline I & + & + & + \\
\hline II & + & - & + \\
\hline III & + & - & - \\
\hline IV & - & + & + \\
\hline V & - & + & - \\
\hline VI & - & - & - \\
\hline
\end{tabular}

Oznaczenia: NI - wynik finansowy netto, $C I$ - wynik całkowity, $O C I$ - pozostały wynik całkowity.

Źródło: [Grabińska, Grabiński, 2012, s. 306].

Przykładowo wariant pierwszy obrazuje najbardziej efektywne zarządzanie finansami przez menedżerów jednostki, gdyż generuje ona dodatni wynik finansowy netto przy jednoczesnym korzystnym wpływie nośników wartości, co finalnie skutkuje dodatnim wynikiem całkowitym. Równie efektywnym zarządzaniem finansami cechuje się wariant drugi, w którym menedżerowie na tyle właściwie gospodarują powierzonymi zasobami, że wystarcza to, mimo niekorzystnych czynników zewnętrznych, do wypracowania dodatniego wyniku całkowitego. Pozostałe warianty pokazują albo pogarszającą się sytuację w otoczeniu jed- 
nostki, z którą menedżerowie mogą mieć w przyszłości problemy (wariant III i VI), albo ewidentnie wskazują na nieefektywne zarządzanie finansami, skutkujące generowaniem straty finansowej netto (warianty IV-VI).

\section{Wyniki badań empirycznych}

Analiza 463 rocznych raportów finansowych spólek przynależnych do indeksu WIG30 oraz DAX ${ }^{1}$, dokonana za lata 2009-2016, wskazuje na zróżnicowanie nie tylko $\mathrm{w}$ formie prezentacji sprawozdania z całkowitych dochodów czy w jego nomenklaturze, ale przede wszystkim $\mathrm{w}$ sposobnie ujmowania komponentów pozostałego wyniku całkowitego i ich nazewnictwie.

Niemieckie spółki stosowały generalnie wersję dwóch sprawozdań, tj. tradycyjnego rachunku zysków i strat (Gewinn- und Verlustrechnung) oraz sprawozdania z zysku całkowitego (Gesamtergebnisrechnung), zaczynającego się od zysku netto i przedstawiającego pozostałe składniki wyniku całkowitego. Polskie jednostki stosowały obydwie wersje - łączną i rozdzielną, nazywając niekiedy tę drugą jednym sprawozdaniem.

W polskich spółkach publicznych zaobserwowano także większe zróżnicowanie w zakresie prezentacji składników pozostałego wyniku całkowitego, tj. zarówno pomniejszonych o określone skutki podatkowe, jak i przed ujęciem skutków podatkowych. Ponadto, część spółek wykazywała wartość podatku szczegółowo dla wszystkich pozycji pozostałego wyniku całkowitego, niektóre zaś ograniczały się jedynie do łącznej jego wartości.

W zakresie nomenklatury tegoż sprawozdania odnotowano natomiast kilka różnych wersji, np. „sprawozdanie z całkowitych dochodów”, „sprawozdanie z wyniku i innych/pozostałych całkowitych dochodów", "sprawozdanie z wyniku finansowego i innych/pozostałych całkowitych dochodów", "sprawozdanie z zysków i strat oraz innych/pozostałych całkowitych dochodów” czy nawet "zestawienie całkowitych dochodów”. Podobnie "pozostały wynik całkowity” określany był jako "pozostałe całkowite dochody", , inne całkowite dochody”, , pozostałe dochody", „inne składniki całkowitych dochodów”.

Liczne rozbieżności zanotowano także $\mathrm{w}$ odniesieniu do nazewnictwa pięciu kategorii komponentów pozostałego wyniku całkowitego, czyli zysków i strat z tytułu przeszacowania składników aktywów finansowych dostępnych do sprzedaży (AFS), efektywnej części zysków i strat związanych z instrumentem zabezpieczającym $w$ ramach zabezpieczania przepływów pieniężnych (HEDGE), zysków i strat aktuarialnych z tytułu programu określonych świadczeń pracowni-

1 Spośród spółek z indeksu WIG30 sześć z nich (Alior, Energa, JSW, PKP Cargo, Play i Tauron) nie prezentowało raportów za wszystkie badane okresy. 
czych (PENS), zmian z przeszacowania składników majątkowych (REV) czy zysków i strat wynikających z przeliczenia pozycji sprawozdania finansowego jednostki działającej za granicą (FOREX). Odrębną kwestią różnicującą badane spółki były ich wartości.

Mając na uwadze szczegółową analizę składników pozostałego wyniku całkowitego, które różnicowały wynik netto od wyniku całkowitego, należy stwierdzić, iż w większości wypadków spółki należące do indeksu DAX wykazywały wszystkie pięć kategorii (tab. 2). Natomiast spółki z indeksu WIG30 notowały przede wszystkim wyceny instrumentów pochodnych zabezpieczających przyszłe przepływy pieniężne, aktywów dostępnych do sprzedaży czy zysków i strat aktuarialnych.

Tabela 2. Średni udział badanych spółek wykazujących elementy pozostałego wyniku całkowitego za lata 2009-2016 (w \%)

\begin{tabular}{|l|c|c|}
\hline \multicolumn{1}{|c|}{ Składniki } & Spółki z WIG30 & Spółki z DAX \\
\hline AFS & 32,5 & 77,1 \\
\hline HEDGE & 48,3 & 99,6 \\
\hline PENS & 32,1 & 82,9 \\
\hline REV & 10,0 & 78,8 \\
\hline FOREX & 10,0 & 93,3 \\
\hline
\end{tabular}

Źródło: Opracowanie własne na podstawie bazy danych Thomson Reuters.

Analiza wartości pozostałego wyniku całkowitego w relacji do wartości kapitału własnego oraz kapitału całkowitego (aktywów całkowitych) wykazała, iż komponenty tegoż wyniku posiadają generalnie mniejsze znaczenie niż wynik finansowy netto (tab. 3).

Tabela 3. Średni udział pozostałego wyniku całkowitego $(O C I)$ i wyniku finansowego netto $(N I)$ w kapitale własnym $(E)$ i aktywach ogółem $(A)$ badanych spółek w latach 2009-2016 (w \%)

\begin{tabular}{|l|l|r|r|r|r|r|r|r|r|}
\hline Wyszczególnienie & Indeks & 2009 & 2010 & 2011 & 2012 & 2013 & 2014 & 2015 & 2016 \\
\hline \multirow{2}{*}{ Udział OCI w E } & WIG30 & 0,1 & 0,2 & 0,03 & 0,5 & 0,4 & 0,2 & 0,1 & 0,6 \\
\cline { 2 - 10 } & DAX & 1,6 & 0,4 & 1,0 & 3,6 & 1,4 & 4,5 & 2,8 & 11,1 \\
\hline \multirow{2}{*}{ Udział NI w E } & WIG30 & 11,2 & 14,2 & 11,9 & 11,5 & 10,3 & 29,7 & 10,6 & 9,5 \\
\cline { 2 - 10 } & DAX & 14,6 & 14,8 & 18,8 & 12,8 & 12,9 & 20,6 & 13,9 & 59,1 \\
\hline \multirow{2}{*}{ Udział OCI w A } & WIG30 & 0,1 & 0,05 & 0,02 & 0,02 & 0,03 & 0,4 & 0,005 & 0,001 \\
\cline { 2 - 10 } & DAX & 1,5 & 1,5 & 0,2 & 1,7 & 0,5 & 1,5 & 1,1 & 0,7 \\
\hline \multirow{2}{*}{ Udział NI w A } & WIG30 & 5,5 & 7,0 & 5,5 & 5,0 & 4,1 & 2,4 & 4,3 & 4,1 \\
\cline { 2 - 10 } & DAX & 9,2 & 4,6 & 8,5 & 6,8 & 6,2 & 9,4 & 5,6 & 4,5 \\
\hline
\end{tabular}

Źródło: Opracowanie własne na podstawie bazy danych Thomson Reuters. 
Wartość wyniku finansowego netto w relacji do wartości kapitału własnego spółek z indeksu WIG30 była średnio o ok. 13 p.p. wyższa niż w przypadku pozostałego wyniku całkowitego. Z kolei w odniesieniu do aktywów całkowitych przewaga sięgała średnio ok. 5 p.p. Dla spółek należących do indeksu DAX różnice te sięgały odpowiednio ok. 18 i 6 p.p.

Należy jednak zauważyć, iż ewidentnie mniejsze znaczenie pozostałego wyniku całkowitego odnotowano w przypadku polskich spółek, gdyż jego udział w kapitale własnym bądź aktywach całkowitych nie przekraczał $1 \%$. W niemieckich spółkach wynosił on średnio kilka procent, a w 2016 r. relacja pozostałego wyniku całkowitego do kapitału własnego wyniosła średnio aż 11,1\%.

Tabela 4. Warianty kształtowania się podstawowych pozycji sprawozdania z całkowitych dochodów badanych spółek (dane za lata 2009-2016)

\begin{tabular}{|c|c|c|c|c|}
\hline \multirow{2}{*}{ Wariant } & \multicolumn{2}{|c|}{ WIG30 } & \multicolumn{2}{c|}{ DAX } \\
\cline { 2 - 5 } & liczba & udział $(w \%)$ & liczba & udział (w \%) \\
\hline I & 72 & 32,3 & 106 & 44,2 \\
\hline II & 126 & 56,5 & 107 & 44,6 \\
\hline III & 1 & 0,5 & 9 & 3,8 \\
\hline IV & 1 & 0,5 & 0 & 0,0 \\
\hline V & 8 & 3,5 & 8 & 3,3 \\
\hline VI & 15 & 6,7 & 10 & 4,1 \\
\hline
\end{tabular}

Źródło: Opracowanie własne na podstawie bazy danych Thomson Reuters.

Oceniając jakość zarządzania finansami spółek należących do indeksu WIG30 oraz DAX na podstawie możliwych wariantów kształtowania się wyniku finansowego netto, pozostałego wyniku całkowitego oraz wyniku całkowitego, podkreślić należy, iż w 88,8\% przypadków dodatnie okazały się zarówno wyniki finansowe netto, jak i wyniki całkowite (wariant I i II), co świadczy o efektywnym gospodarowaniu zasobami przez menedżerów tych jednostek (tab. 4). Polskie spółki znacznie częściej generowały jednak dodatni wynik finansowy netto przy jednocześnie niekorzystnym wpływie czynników zewnętrznych. Wpływ ten okazał się jednak znikomy, co pozwoliło na wypracowanie dodatniego wyniku całkowitego. Wyniki przeprowadzonych badań empirycznych potwierdzają także, że spółki należące do indeksu WIG30 częściej notowały ujemne wyniki finansowe, zarówno na poziomie netto, jak i całkowitym. 


\section{Podsumowanie}

Opisywane szeroko w literaturze przedmiotu strategie i techniki zarządzania finansami przedsiębiorstw ( $\mathrm{w}$ tym zarządzania zyskiem) $\mathrm{w}$ większości przypadków koncentrują się na zysku lub stracie netto oraz odnoszą się do wyceny, szacunków oraz kształtowania transakcji, za pomocą których zmienia się wysokość kosztów i przychodów danego okresu. Cel zastosowania kategorii wyniku całkowitego oraz jego komponentów w sprawozdawczości finansowej stanowiło dostarczanie informacji przydatnych m.in. menedżerom $w$ podejmowaniu decyzji, które pomagają w przewidywaniu przyszłych wyników. Nietrudno jednak zauważyć swego rodzaju rozdźwięk między harmonizacją na poziomie pojęć, ujmowania i wyceny podstawowych kategorii a dużą dowolnością co do formy prezentacji informacji [Gierusz, 2013].

Przytoczone w artykule wybrane zróżnicowane poglądy na temat zalet i wad wyniku całkowitego w zarządzaniu finansami przedsiębiorstw sugerują potrzebę głębszej oceny komponentów pozostałego wyniku całkowitego oraz ich użyteczności decyzyjnej $\mathrm{w}$ porównaniu z generatorami wyniku finansowego netto. Niewątpliwie wynik finansowy ustalony $\mathrm{w}$ rachunku zysków i strat oraz jego struktura wskazują na rentowność osiągniętą $\mathrm{w}$ danym okresie, a pozostały wynik całkowity informuje o potencjalnych zyskach lub stratach, które jednostka odnotuje $\mathrm{w}$ następnych okresach, a które już w bieżącym okresie spowodowały zmiany po stronie kapitału własnego.

Wyniki komparatywnych badań empirycznych spółek należących do indeksu WIG30 oraz DAX potwierdziły niejednolitość w zakresie form i zasad prezentacji wyniku całkowitego, jego struktury oraz poszczególnych pozycji, zwłaszcza składników pozostałego wyniku całkowitego. Bez wątpienia większą różnorodnością w tym zakresie cechowały się spółki z polskiego parkietu, mimo iż nie wykazywały one w wielu przypadkach poszczególnych kategorii mieszczących się w sprawozdaniu z całkowitych dochodów.

Oceniając przydatność kategorii pozostałego wyniku całkowitego w zarządzaniu finansami przedsiębiorstw na podstawie jego relacji w stosunku do kapitału własnego i kapitału całkowitego, należy wskazać, iż w spółkach z indeksu WIG30 odnotowano znacznie mniejsze proporcje między tymi kategoriami aniżeli w spółkach z indeksu DAX. Ponadto, niemieckie przedsiębiorstwa znacznie częściej generowały dodatnie wartości pozostałego wyniku całkowitego, co obrazowało efektywne wzmacnianie wypracowanego przez menedżerów wyniku finansowego netto. Przeprowadzona analiza nie dostarcza jednak wystarczających dowodów na to, że wynik całkowity tworzy dla kierownictwa jednostek dodatkową wartość. Ujawnianie tych wyników dla potrzeb zarządczych może z jednej strony wydawać się więc wątpliwe, ale z drugiej może zachęcić menedżerów do bardziej 
oportunistycznego zarządzania zyskiem i analizy błędnych wniosków wyciąganych ze sprawozdań finansowych.

Bibliografia

Black F., 1993, Choosing accounting rules, Accounting Horizons, vol. 7, no. 4.

Cahan S.F., Courtenay S.M., Gronewoller P.L., Upton D.R., 2000, Value Relevance of Mandated Comprehensive Income Disclosures, Journal of Business Finance \& Accounting, vol. 27, no. $9 / 10$.

Chambers D., Linsmeier T., Shakespeare C., Sougiannis T., 2007, An Evaluation of SFAS No. 130 Comprehensive Income Disclosure, Review of Accounting Studies, vol. 12, no. 4.

Cimini R., 2013, Reporting Comprehensive Income Issues. Empirical Evidence from France, Germany and Italy, Economia Aziendale Online, vol. 4, no. 1.

Dastgir M., Velashani A.S., 2008, Comprehensive income and net income as measures of firm performance. Some evidence for scale effect, European Journal of Economics, Finance and Administrative Sciences, vol. 12.

Dhaliwal D., Subramanyam K.R., Trezevant R., 1999, Is Comprehensive Income Superior to Net Income as a Measure of Firm Performance, Journal of Accounting and Economics, vol. 26, no. $1-3$.

Gierusz J., 2013, Postulowana forma ujawnień w sprawozdaniu z całkowitych dochodów, Prace Naukowe Uniwersytetu Ekonomicznego we Wrocławiu, nr 314.

Grabińska B., Grabiński K., 2012, Propozycja interpretacji podstawowych pozycji sprawozdania z zysku całkowitego sporzadzonego zgodnie z MSR 1, Zeszyty Naukowe Uniwersytetu Ekonomicznego w Krakowie, nr 13.

Hirst D.E., Hopkins P.E., 2007, Comprehensive Income Disclosure and Analysts' Valuation Judgements, Journal of Accounting Research, vol. 36, no. 3.

Jones D.A., Smith K.J., 2011, Comparing the Value Relevance, Predictive Value, and Persistence of Other Comprehensive Income and Special Items, The Accounting Review, vol. 86, no. 6.

Kanagaretman K., Mathieu R., Shehata M., 2009, Usefulness of Comprehensive Income Reporting in Canada, Journal of Accounting and Public Policy, vol. 28, no. 4.

Keating M., 1999, An Analysis of the Value of Reporting Comprehensive Income, Journal of Accounting Education, vol. 17.

Le Manh-Béna A., 2009, Is Comprehensive Income Required by IAS 1 Relevant for Users? A Review of the Literature, ESCP Europe Working Paper, https://halshs.archives-ouvertes.fr/ halshs-00494511 [dostęp: 15.01.2018].

Maines L.A., McDaniel L.S., 2000, Effects of Comprehensive-Income Characteristics on Nonprofessional Investors' Judgments. The Role of Financial-Statement Presentation Format, The Accounting Review, vol. 75, no. 2.

MSR, 2011, Międzynarodowe Standardy Rachunkowości, IFRS Foundation, Stowarzyszenie Księgowych w Polsce, Warszawa.

Pronobis P., Zülch H., 2011, The predictive power of comprehensive income and its individual components under IFRS, Problems and Perspectives in Management, vol. 9, no. 4.

Ramond O., Casta J.F., Lin S., 2007, Value Relevance of Comprehensive Income. Evidence from Major European Capital Markets, European Accounting Association, Lisbon.

Sajnóg A., 2017, Wartość predykcyjna zysku całkowitego spółek akcyjnych, Acta Universitatis Lodziensis. Folia Oeconomica, nr 2. 
Szychta A., de la Rosa D., 2012, Comprehensive Income Presentation under IAS 1: The Reporting Practices of the Largest Companies Listed on the Warsaw Stock Exchange, Zeszyty Teoretyczne Rachunkowości, nr 68.

Turyna J., 2003, Standardy Rachunkowości, MSR - USGAAP - Polskie ustawodawstwo, Difin, Warszawa.

A. Sajnóg (『) asajnog@uni.lodz.pl Wydział Ekonomiczno-Socjologiczny, Uniwersytet Łódzki, ul. POW 3/5, 90-255 Łódź, Polska 